\title{
Quality of life among Primary Schools Children with Refractive Errors in Menoufia, Egypt
}

Nagwa N. Hegazy ${ }^{1}$, Nagwa A. Farag ${ }^{1 *}$, Zynab Kasemy ${ }^{2}$

${ }^{1}$ Family Medicine Department, Faculty of Medicine, Menoufia University

${ }^{2}$ Public Health and Community Medicine Department, Faculty of Medicine, Menoufia University

\begin{abstract}
:
Background: Refractive error is the powerlessness of the eye to light into focus on the retina resulting in nearsightedness (myopia), farsightedness (Hyperopia) or astigmatism. Uncorrected refractive error in children is connected with impaired quality of life, increased morbidity and reduced educational opportunities. Objectives: This study aims to assess the impact of refractive errors on the quality of life (QOL) of Primary Schools Children. Methods: This cross section study was conducted on 960 ( 6-12 years old) primary school children in the first, second and third grades attended Munshaat Sultan primary school, Menouf district, Menoufia, Egypt from 1st October 2016 to the end of December 2016. The participants were assessed through a questionnaire which includes (socio-demographic data and comprehensive history), general and visual examination. QOL of participants with refractive errors was assessed using semi structured questionnaire that consisted of 7 items. The reliability of questionnaires was tested using Cronbach's alpha which was 0.953. Results: Out of 960 students $232(24.1 \%)$ had a significant refractive error of \pm 0.50 in one or both eyes. There was a highly statistically significant difference between participated children with and without error of refraction regarding socioeconomic status and all parameters of QOL ( $p$ value $<0.001$ ). Overall $45.5 \%$ of students with error of refraction had poor QOL. Conclusion: Screening for refractive errors in primary school children is mandatory to start corrective measures at the early stage, and improve their quality of life.
\end{abstract}

Key words: PHC, Quality of life, Visual errors

Introduction: Refractive errors are the most common ocular problem affecting all age groups especially among school-age children. They are considered a public health challenge. ${ }^{(1)}$ The WHO reports indicate that refractive errors are the first cause of visual impairment and the second cause of visual loss worldwide as $43 \%$ of visual impairments are attributed to refractive errors. ${ }^{(2,3)}$ The prevalence of error of refraction is increasing worldwide especially in children due to misuse of electronic devices. It is estimated to be $70-90 \%$ in some Asian countries ${ }^{(4)}, 50 \%$ in England, ${ }^{(5)} 25 \%$ in North America and in Iran is estimated to be $21 \%^{(6)}$ In addition to nationality sex and race affect the chance and prevalence of error of refraction. It is higher in females than males and in whites than black race. $^{(7)}$

In Egypt 2007 A survey conducted in Cairo governorate among 5839 Egyptian school children aged 7-15 years found that the prevalence of refractive errors (visual acuity $\leq 6 / 12$ ) was $22.1 \%{ }^{\left({ }^{(8)}\right.}$ Also a preliminary national survey done in the Helwan area of Cairo reported that $34 \%$ of the recorded disabilities were visual disability ${ }^{(9)}$. In 2015 study conducted in Menouf district, 
Egypt to study prevalence of refractive errors among primary school children that was $24 \%$ had refractive errors. Of them, $22 \%$ patients had myopia and only $2 \%$ had hypermetropia. ${ }^{(10)}$

Uncorrected refractive errors impair the quality of life of millions of people with different ages, genders, and ethnicities and they impose heavy burdens on the families of the affected individuals as well as the society as a result of loss of manpower. Moreover, uncorrected refractive errors at young ages can lead to amblyopia which negatively affects their educational, occupational, and athletic performance. ${ }^{(11)}$ In addition to social, economic and educational consequences it can lead to problems in a person's quality of life related to vision and makes it difficult for them to do tasks pertinent to it. ${ }^{(12)}$

A strong relationship is reported between refractive errors, reading problems in school age students; reduce their academic performance in schools. Later on it reduce employability and productivity. ${ }^{(13)}$ The importance of patient-based measurements for measuring their quality of life has nowadays been recognized and accordingly numerous quality of life questionnaires have been developed. ${ }^{(14)}$ Consequently evaluating the quality of life related to refractive error and vision performance based on patient views has increased in recent decades. Measuring the quality of life might be a great help to us to reach a correct comprehension of needs, decisions, treating and elevating the personal and social level of a person's life. ${ }^{(15)}$

Methods: This case-controlled crosssectional study was conducted in all primary schools (4 schools; New Fatah School, El Shahied Shaban School, El Refae El Azhare School and El Road schools) in Munshat Sultan village, Menouf district, Menoufia governorate, Egypt.The catchment area of family health center of Suzan Mubarak hospital which one of the main family health center in Menoufia governorate. One class from the first to the third grade was selected through systematic random sampling. The sample size for the study was estimated to be 960 students by using Epi Info (Clifton Road Atlanta, GA, USA) for windows with an error of $1 \%$ based on prevalence of error of refraction which was30.1 $\%^{(10)}$ consider power of study $80 \%$ and $95 \%$ confidence interval.

The number of children in the primary schools was 1800 child aged 6-12 years. By systemic random sample every second name in the list was included in the study. The total numbers were 981 students but only 960 students were eligible and had participated in the study as: visual examination showed that 
33 were excluded (31wearing glasses and 2 had congenital cataract). All participant underwent interviewing and examination. All selected students with help of the social workers were interviewed using a semi structured questionnaire. The first part of the questionnaire aimed to assess the socioeconomic status as age, sex, ... according to El-Gilany et al. ${ }^{(16)}$ The second part of the questionnaire aimed to assess eye problems \& daily activity such as (Lipoma, led drop, led Inversion and led Extroversion) , Vision defect, family history of low vision, eye strain, see the way to bathroom, Watching clock and see the board writing. The third part of the questionnaire aimed to assess the quality of life.

It was developed by the research team in Arabic language based on information from literature review from the WHO (2006) ${ }^{(12)}$ and Centers for Disease Control (CDC)(2007) ${ }^{(17)}$.The questionnaire entails 7 items (Feeling happiness, Doing everything easily, Feeling angry when doing things ,Stud. Work, Understanding, Achievement and Planning with friends). A score for each answer on questions of QOL was given $(2=$ yes and $1=$ no).The QOL was considered good if percentage of the score equals $75-100 \%$ and poor if percentage of score is less than $75 \%$. The reliability of questionnaires was tested using Cronbach's alpha which was 0.953(Table 1). We develop this tools from WHO and CDC because it more practical and available for us. In addition to the questionnaires of refractive error and quality of life are too long to apply for children.

Statistical analysis: The results were analyzed statistically using Microsoft Excel and SPSS, version 17 software programs (SPSS Inc., Chicago, Illinois, USA). Data were described as range, mean, SD, frequencies (number of cases), and relative frequencies (percentages) when appropriate. A $\mathrm{P}$ value less than 0.05 was considered statistically significant.

Ethical consideration: The study was approved by the Ethical Committee of the Faculty of Medicine, Menoufia University. An official permission letter was obtained from the author and directed to the administrators of selected school. A written consent was obtained from the children guardians. the participants were ensured as to their anonymity and confidentiality of recorded data. They were also justified with regard to the purpose and its conduct method.

Results: Nine hundred and sixty students had participated in the study. Twenty- four (24\%) had a significant refractive error of \pm 0.50 or worse in one or both (Figure 1). About $28.8 \%$ of the children families were very low 
socioeconomic status (Table 2). Regarding eye status Most children ( 50.4\%) complained of lipoma whereas about $74.2 \%$ complain of eye strain when looking to sun. about $24.2 \%$ has vision defect and $59.2 \%$ has family history of low vision with $64.3 \%$ of them with mother history of low vision. $16.9 \%$ of children cannot see the board from where they sit So they go to front near the board (Table $3)$.

Most children reported that they had limitation in performing day to day activities as feeling angry when doing things, planning with friends, achievement, doing everything easily. Study homework, understanding, feeling happiness with poor quality score in $(86.9 \%)$ of them (Table 4). There was a statistically significant difference between participated child with and without error of refraction regarding socioeconomic status and all parameters of QOL ( $\mathrm{p}$ value $<0.001$ ). More than forty percent $(45.5 \%)$ of students with error of refraction had poor QOL (Table 5 and Table 6).

Discussion: An uncorrected refractive error remains a public health problem among different population groups. School children with uncorrected refractive errors have a considerable impact on learning and academic achievement especially in underserved and under resourced communities. Visual impairment from uncorrected refractive errors might have immediate and long-term consequences education on educational and employment opportunities. And also affect the ability to earn for individuals, families and societies and impaired quality of life. ${ }^{(18)}$

In a review study, Naidoo et al. ${ }^{(3)}$ showed that uncorrected refractive errors were responsible for visual impairment in 101.2 million people and blindness in 6.8 million people in 2010 worldwide. In the present study the prevalence of refractive errors was found to be $24 \%$ in children aged $6-12$ years. This was in agreement with El-Bayoumy ${ }^{(8)}$ study that conducted in Cairo, Egypt, who found that the prevalence of refractive errors in school students aged 7-14 years to be nearly $22.1 \%$. It also, agreement with Mohamed et $\mathrm{al}^{(10)}$ conducted study in Menoufia governorate found that the prevalence of refractive errors in school students aged 10-15 years was $24.7 \%$. Another cross-sectional analysis of 2070 healthy primary school children screened for refractive errors from 2009 through 2010 in the cities of South Sinai, Egypt and their surrounding Bedouin settlements found that the prevalence of refractive errors was $29.4 \%$. ${ }^{(20)}$

Most children reported that they had limitation in performing day to day activities 
as Feeling angry when doing things , Planning with friends, Achievement, Doing everything easily. Study homework, Understanding, Feeling happiness with poor quality score in $(86.9 \%)$ of them. It is consistent with Kandel et $\mathrm{al}^{(21)}$ who founded that there is activity limitations (difficulties in performing day-to-day activities) as the result of refractive error have a huge impact on people's life. This is probably the major reason for people seeking refractive correction.

There was a statistically significant difference between children with refractive errors and normal children regarding age and socioeconomic status and family history of low vision ( $\mathrm{p}<0.001)$. This result is in disagreement with a Pakistani study ${ }^{(18)}$ showing that 61 out of 107 students who had refractive errors had a positive familial history of using glasses and this indicates a strong relationship between refractive errors and family factor. In other hand it contradicted to Farahata et al ${ }^{(19)}$ who reported insignificant statistical difference between children.

There was a statistically significant difference between children with refractive errors and normal children regarding daily activities and their quality of life in all parameters $(\mathrm{p}<0.001)$. This was agreed with
Sturrock et al. ${ }^{(22)}$ who study Vision-Related Quality of Life in Patients with Low Vision in a Prospective Longitudinal Study. Overall $45.5 \%$ of students with error of refraction had poor QOL. This was in agreement with Pakpour et al. ${ }^{(23)}$ that done in Iranian study, which studied the relationship between Psychometric properties and quality of life.

\section{References:}

1. Lian-Hong Pi1, Lin Chen1, Qin Liu1, Ning Ke1, Jing Fang1, Shu Zhang1, Jun Xiao1, Wei-Jiang Ye1, Yan Xiong1, Hui Shi1, Zheng-Qin Yin(2010): RefractiveStatus and Prevalence of Refractive Errors in Suburban School-age Children. Int. J. Med. Sci.; 7(6):342353.last accesses 20 August 2018.

2. Naidoo KS, Leasher J, Bourne RR, et al. Global vision impairment and blindness due to uncorrected refractive error, 1990e2010. Optom Vis Sci. 2016;93(3):227e234

3. Pascolini D, Mariotti SP. Global estimates of visual impairment: 2010. $\mathrm{Br} \quad \mathrm{J}$ Ophthalmol. 2012;96(5):614e618.

4. Douglas RK. Myopia.BMJ.2002; 324:1195.

5. Garamandi E., Pesodous K., Elliot D ( 2005): Changes in quality of life after laser in situ keratomileusis for myopia. J 
Cataract Refract Surg. 2005;31:15371543.

6. Hashemi H., Fotouhi A., Mohammad $\mathrm{K}(2004)$ : The age and gender specific prevalence of refractive errors in Tehran: the Tehran eye study. Ophthalmic Epidemiology. 2004;11:213-225.

7. Sperdato R.D., Seigel D., Roberts J., Rowland M. Prevalence of myopia in United States. Arc Ophthalmol. 1983;101:405-407.

8. El-Bayoumy BM, Saad A, Choudhury AH. (2007):Prevalence of refractive error and low vision among school children in Cairo. East Mediterr Health J. 2007;13:575-9.

9. Shukrallah,A., Mostafa, H. and Magdi, S. 1997:The Current State of the Disability Question in Egypt: Preliminary National Study. Presented to North-South Inserm Network.

10. Mohammed M. Elkot, Faried M. Wgdy , Nagwa N. Hegazy, Asmhan F. Hamouda ( 2015): Prevalence of refractive errors among primary school children in the rural areas of Menouf district, Egypt. Menoufia Med J 29:1044-104

11. Naidoo KS, J. JaggernathUncorrected refractive errors Indian J Ophthalmol, 60 (5) (2012), pp. 432-437.
12. World Health Organization (WHO) (2006). Prevention of Blindness and Deafness. Available data on blindness, update 2006. Geneva: WHO; 2006. Retrieved from http://www.who.int/blindness/publications /global_data.pdf. Last accesses 3 June 2018.

13. Handler SH and Fierson WM (2011): Learning disabilities, dyslexia, and vision. ; American Academy of Pediatric.127,818-856.

14. Ahangari M. Iran University of Medical Sciences; Iran: 2005. Study of Quality of Life in Seniors of Tehran.

15. Ziai H., Katibeh M,Sabbaghi M., Yaseri M. Quality of life in myopia corrected with photorefractive keratectomy, contact lenses and spectacles. Bina J Ophthalmol. 2011;17:148-154.

16. El-Gilany A, El-Wehady A, El-Wasify M. Updating and validation of the socioeconomic status scale for health research in Egypt. East Mediterr Health J2012; 18:962-968.

17. Centers for Disease Control and Prevention (CDC): National Center for Health Statistics (NCHS). National Health and Nutrition Examination Survey. Weighted and un weighted 
response rates for NHANES by gender and age. Hyattsville, MD: U.S. Department of Health and Human Services, Centers for Disease Control and Prevention; 2007. [Accessed 27 July 2007].

18. Resnikoff S, Pascolini D, Mariotti S. P, Pokharel G. P. Global magnitude of visual impairment caused by uncorrected refractive errors (2004): Geneva: WHO bulletin;

2004.http://www.who.int/bulletin/volumes /86/1/07-041210/en/index.html.

19. Farahata HG, G. Marey HM, Badawi NM, Allam HK, M. Issa MM. Prevalence of occult refractive errors in primary school students. Menoufia Med J 2018;31:26772.

20. Yamamah GA, Talaat Abdel Alim AA, Mostafa YS, Ahmed RA, Mahmoud AM. Prevalence of visual impairment and refractive errors in children of South
Sinai, Egypt. Ophthalmic Epidemiol 2015; 22:246-252.

21. Kandel H, Khadka J, Lundstrom M, Goggin M, Pesudovs K. Questionnaires for measuring refractive surgery outcomes. J Refract Surg 2017; https://doi.org/ 10.1007/978-3-540-375845.

22. Sturrock BA, Xie J, Holloway EE et al. The influence of coping on vision-related quality of life in patients with low vision: a prospective longitudinal study. Invest Ophthalmol Vis Sci 2015; 56: 2416.

23. Pakpour A.H., Zeidi I.M., Saffari M., Labiris J., Fridlund B. Psychometric properties of the national eye institute refractive error correction quality of life questionnaire among Iranian patients. Oman J Ophthalmol. 2013;6:37-43. 


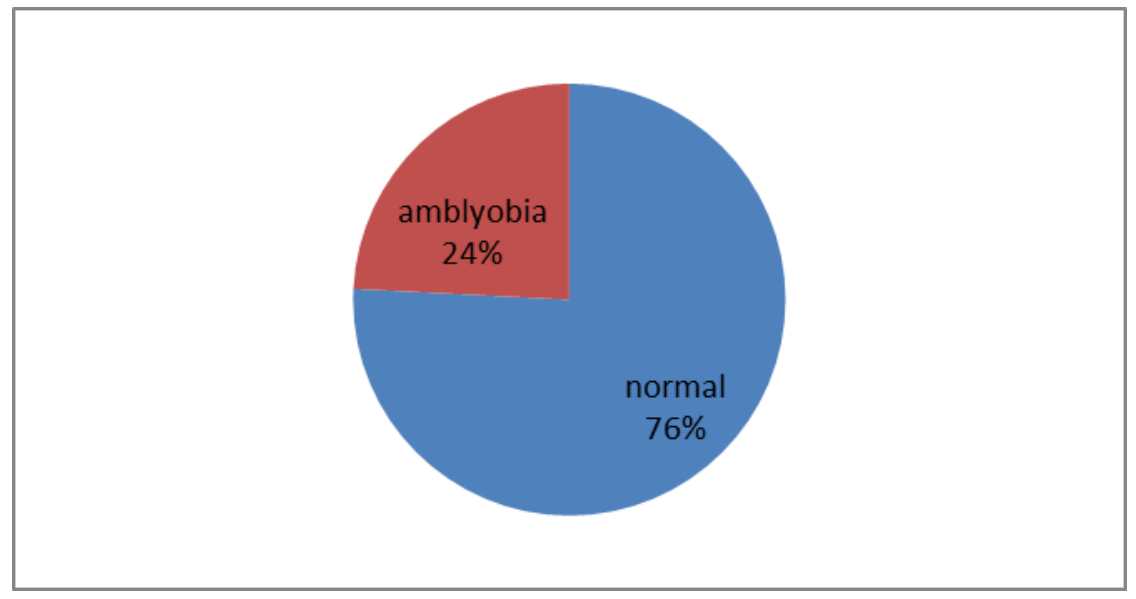

Fig (1): Percentage of refractive errors among studied children

Table (1): Validity of the questionnaire for quality of life and daily activity

\begin{tabular}{|c|c|c|}
\hline \multicolumn{3}{|c|}{ Reliability Statistics } \\
\hline Cronbach's Alpha & $\begin{array}{c}\text { Cronbach's Alpha Based } \\
\text { on Standardized Items }\end{array}$ & No. of Items \\
\hline 0.953 & 0.949 & \\
\hline
\end{tabular}


Table (2): Socio-demographic characteristics of the studied children

\begin{tabular}{|c|c|c|c|c|c|}
\hline $\begin{array}{l}\text { Socio-demographic } \\
\text { Characteristics }\end{array}$ & \multicolumn{5}{|c|}{$(\mathrm{No}=960)$} \\
\hline $\begin{array}{l}\text { - Child's Age (years) } \\
\text { - Mean } \pm \text { SD*/ Range }\end{array}$ & \multicolumn{5}{|c|}{$10.49 \pm 1.62 / 7-12$} \\
\hline $\begin{array}{l}\text { - Father's Age (years) } \\
\text { - Mean } \pm \text { SD /Range }\end{array}$ & \multicolumn{5}{|c|}{$42.79 \pm 6.11 / 24-62$} \\
\hline $\begin{array}{l}\text { - Mother's Age (years) } \\
\text { - Mean } \pm \text { SD/ Range }\end{array}$ & \multicolumn{5}{|c|}{$37.45 \pm 5.70 / 23-51$} \\
\hline \multirow[b]{2}{*}{$\begin{array}{l}\text { Mother's education } \\
\text { - Illiterate } \\
\text { - Read \& write } \\
\text { - Basic } \\
\text { - Secondary } \\
\text { - Middle institute } \\
\text { - University } \\
\text { - Postgraduate }\end{array}$} & No & $\%$ & & No & $\%$ \\
\hline & $\begin{array}{c}28 \\
94 \\
184 \\
280 \\
68 \\
300 \\
6\end{array}$ & $\begin{array}{c}2.9 \\
9.8 \\
19.2 \\
29.2 \\
7.1 \\
31.2 \\
0.6 \\
\end{array}$ & $\begin{array}{l}\text { Father's education } \\
\text { - } \quad \text { Illiterate } \\
\text { - } \text { Read \& write } \\
\text { - } \quad \text { Basic } \\
\text { - } \quad \text { Secondary } \\
\text { - } \text { Middle institute } \\
\text { - } \quad \text { Pniversity } \\
\end{array}$ & $\begin{array}{c}26 \\
82 \\
126 \\
134 \\
236 \\
350 \\
6\end{array}$ & $\begin{array}{c}2.7 \\
8.5 \\
13.1 \\
24.6 \\
14.0 \\
36.5 \\
0.6\end{array}$ \\
\hline $\begin{array}{l}\text { Mother's occupation } \\
\text { - Housewife } \\
\text { - Unskilled } \\
\text { - Employee } \\
\text { - Business } \\
\text { - Professional }\end{array}$ & $\begin{array}{c}738 \\
8 \\
62 \\
4 \\
148\end{array}$ & $\begin{array}{c}76.9 \\
0.8 \\
6.5 \\
0.4 \\
15.4\end{array}$ & $\begin{array}{ll}\text { Father's occupation } \\
\text { - } \quad \text { Worker } \\
\text { - } \quad \text { Farmer } \\
\text { - } \quad \text { Skilled } \\
\text { - } \text { Employee } \\
\text { - } \quad \text { Business } \\
\text { - } \quad \text { Professional } \\
\end{array}$ & $\begin{array}{c}152 \\
30 \\
76 \\
264 \\
146 \\
292\end{array}$ & $\begin{array}{c}15.8 \\
3.1 \\
7.9 \\
27.5 \\
15.2 \\
30.4\end{array}$ \\
\hline $\begin{array}{l}\text { Income } \\
\text { - Not enough } \\
\text { - Enough } \\
\text { - More than enough }\end{array}$ & $\begin{array}{l}136 \\
676 \\
148\end{array}$ & $\begin{array}{l}14.2 \\
70.4 \\
15.4\end{array}$ & $\begin{array}{l}\text { SES** } \\
\text { - Very low } \\
\text { - } \text { Low } \\
\text { - } \text { Moderate } \\
\text { - High }\end{array}$ & $\begin{array}{l}276 \\
284 \\
218 \\
182\end{array}$ & $\begin{array}{l}28.8 \\
29.6 \\
22.7 \\
19.0\end{array}$ \\
\hline
\end{tabular}

*SD: standard deviation

*SES: socioeconomic status 
Table (3): Eye status and daily activities of the studied children

\begin{tabular}{|c|c|c|}
\hline Studied variables & No(960) & $\%$ \\
\hline $\begin{array}{l}\text { Complaint } \\
\text { - } \quad \text { Lipoma } \\
\text { - } \quad \text { Led drop } \\
\text { - } \quad \text { Led Inversion } \\
\text { - } \quad \text { Led Extroversion }\end{array}$ & $\begin{array}{c}484 \\
302 \\
158 \\
16\end{array}$ & $\begin{array}{c}50.4 \\
31.5 \\
16.5 \\
1.7\end{array}$ \\
\hline $\begin{array}{l}\text { Eye strain occurs when looking at the sun } \\
\text { - No } \\
\text { - Yes }\end{array}$ & $\begin{array}{l}248 \\
712\end{array}$ & $\begin{array}{l}25.8 \\
74.2\end{array}$ \\
\hline $\begin{array}{l}\text { Vision defect } \\
\text { - } \quad \text { No } \\
\text { - } \quad \text { Yes }\end{array}$ & $\begin{array}{l}728 \\
232\end{array}$ & $\begin{array}{l}75.8 \\
24.2\end{array}$ \\
\hline $\begin{array}{l}\text { Family history of low vision } \\
\text { - } \quad \text { Yes } \\
\text { - } \quad \text { No }\end{array}$ & $\begin{array}{l}392 \\
568\end{array}$ & $\begin{array}{l}40.8 \\
59.2\end{array}$ \\
\hline $\begin{array}{l}\text { Who in family with low vision }(\mathbf{n}=\mathbf{3 9 2}) \\
\text { - } \text { Mother } \\
\text { - } \text { Grand father } \\
\text { - } \text { Grand mother }\end{array}$ & $\begin{array}{c}252 \\
108 \\
32\end{array}$ & $\begin{array}{c}64.3 \\
27.6 \\
8.2\end{array}$ \\
\hline $\begin{array}{l}\text { Eye strain } \\
\text { - } \quad \text { Always } \\
\text { - } \quad \text { Often } \\
\text { - } \quad \text { Sometimes } \\
\text { - } \quad \text { Rare }\end{array}$ & $\begin{array}{c}4 \\
26 \\
206 \\
724\end{array}$ & $\begin{array}{l}0.4 \\
2.7 \\
21.5 \\
75.4\end{array}$ \\
\hline $\begin{array}{l}\text { Can see the way to bathroom } \\
\text { - } \quad \text { No } \\
\text { - } \quad \text { Yes }\end{array}$ & $\begin{array}{c}22 \\
938\end{array}$ & $\begin{array}{c}2.3 \\
97.7\end{array}$ \\
\hline $\begin{array}{l}\text { Watching clock } \\
\text { - } \quad \text { No } \\
\text { - } \quad \text { Yes }\end{array}$ & $\begin{array}{l}114 \\
846\end{array}$ & $\begin{array}{l}11.9 \\
88.1\end{array}$ \\
\hline $\begin{array}{l}\text { Can see the board writing } \\
\text { - } \quad \text { No } \\
\text { - } \quad \text { Yes }\end{array}$ & $\begin{array}{l}162 \\
798\end{array}$ & $\begin{array}{l}16.9 \\
83.1\end{array}$ \\
\hline
\end{tabular}


Table (4): Quality of life of the studied children

\begin{tabular}{|c|c|c|c|c|}
\hline \multirow{2}{*}{ Quality of life } & \multicolumn{4}{|c|}{ No.(960) } \\
\cline { 3 - 6 } & \multicolumn{3}{|c|}{ Yes } & \multicolumn{2}{c|}{ No } \\
\cline { 2 - 6 } - & No & $\%$ & No & $\%$ \\
\hline - Doing everything easily & 204 & 21.2 & 756 & 78.7 \\
\hline - Feeling angry when doing things & 78 & 8.1 & 882 & 85.0 \\
\hline - Stud. Work & 144 & 15.0 & 816 & 91.9 \\
\hline - Understanding & 152 & 15.8 & 808 & 84.2 \\
\hline - Achievement & 156 & 16.2 & 804 & 83.8 \\
\hline - Planning with friends & 124 & 12.9 & 836 & 87.1 \\
\hline Total score & 102 & 10.6 & 858 & 89.4 \\
\hline - Poor & \multicolumn{2}{|c|}{ No } & & \multicolumn{2}{c|}{86.9} \\
\hline
\end{tabular}


Table (5): Distribution of examined students with vision defect according to their personal characteristics and their daily activities

\begin{tabular}{|c|c|c|c|c|c|c|}
\hline & \multicolumn{4}{|c|}{ Vision defect } & \multirow{3}{*}{$\begin{array}{c}\chi^{2} \\
\text { Test }\end{array}$} & \multirow[t]{3}{*}{$P$ value } \\
\hline & \multicolumn{2}{|c|}{ Yes } & \multicolumn{2}{|c|}{ No } & & \\
\hline & $\begin{array}{l}\text { No } \\
(232)\end{array}$ & $\%$ & $\begin{array}{c}\text { No } \\
(\mathbf{7 2 8})\end{array}$ & $\%$ & & \\
\hline $\begin{array}{l}\text { Age (years) } \\
\text { Mean SD/ Range }\end{array}$ & \multicolumn{2}{|c|}{$10.9 \pm 1.6$} & \multicolumn{2}{|c|}{$11.7 \pm 1.8$} & 5.2 & $<0.001^{*}$ \\
\hline \begin{tabular}{ll}
\multicolumn{2}{l}{ SES } \\
- $\quad$ Very low \\
- $\quad$ Low \\
- $\quad$ Moderate \\
- $\quad$ High \\
\end{tabular} & $\begin{array}{l}36 \\
78 \\
46 \\
72 \\
\end{array}$ & $\begin{array}{l}13.0 \\
27.5 \\
21.1 \\
39.6 \\
\end{array}$ & $\begin{array}{l}240 \\
206 \\
172 \\
110\end{array}$ & $\begin{array}{l}87.0 \\
72.5 \\
78.9 \\
60.4 \\
\end{array}$ & 44.97 & $<0.001^{*}$ \\
\hline $\begin{array}{l}\text { Family history of low } \\
\text { vision } \\
\text { - Yes } \\
\text { - } \quad \text { No } \\
\end{array}$ & $\begin{array}{l}110 \\
122\end{array}$ & $\begin{array}{l}28.1 \\
21.5\end{array}$ & $\begin{array}{l}282 \\
446\end{array}$ & $\begin{array}{l}71.9 \\
78.5\end{array}$ & 5.48 & $<0.001^{*}$ \\
\hline \begin{tabular}{ll}
\multicolumn{2}{l}{ Eye strain } \\
- & Always \\
- & Often \\
- & Sometimes \\
- & Rare \\
\end{tabular} & $\begin{array}{l}36 \\
78 \\
46 \\
72 \\
\end{array}$ & $\begin{array}{l}13.0 \\
27.5 \\
21.1 \\
39.6 \\
\end{array}$ & $\begin{array}{l}240 \\
206 \\
172 \\
110\end{array}$ & $\begin{array}{l}87.0 \\
72.5 \\
78.9 \\
60.4 \\
\end{array}$ & 44.97 & $<0.001^{*}$ \\
\hline $\begin{array}{l}\text { Eye strain occurs when } \\
\text { looking at the sun } \\
\text { - No } \\
\text { - Yes } \\
\end{array}$ & $\begin{array}{c}214 \\
18 \\
\end{array}$ & $\begin{array}{c}92.2 \\
7.8 \\
\end{array}$ & $\begin{array}{c}34 \\
694 \\
\end{array}$ & $\begin{array}{c}4.7 \\
95.3 \\
\end{array}$ & 704.20 & $<0.001^{*}$ \\
\hline $\begin{array}{l}\text { Can see the way to } \\
\text { bathroom } \\
\text { - No } \\
\text { - Yes } \\
\end{array}$ & $\begin{array}{c}22 \\
210\end{array}$ & $\begin{array}{c}9.5 \\
90.5\end{array}$ & $\begin{array}{c}0 \\
728\end{array}$ & $\begin{array}{c}0.0 \\
100.0\end{array}$ & 70.65 & $<0.001^{*}$ \\
\hline $\begin{array}{l}\text { Watching clock } \\
\text { - No } \\
\text { - Yes } \\
\end{array}$ & $\begin{array}{l}114 \\
118 \\
\end{array}$ & $\begin{array}{l}49.1 \\
50.9\end{array}$ & $\begin{array}{c}0 \\
728 \\
\end{array}$ & $\begin{array}{c}0.0 \\
100.0\end{array}$ & 405.90 & $<0.001^{*}$ \\
\hline $\begin{array}{l}\text { Can see the board writing } \\
\text { - No } \\
\text { - Yes }\end{array}$ & $\begin{array}{c}162 \\
70\end{array}$ & $\begin{array}{l}69.8 \\
30.2\end{array}$ & $\begin{array}{c}0 \\
728\end{array}$ & $\begin{array}{c}0.0 \\
100.0\end{array}$ & 611.5 & $<0.001^{*}$ \\
\hline $\begin{array}{l}\text { Setting at TV } \\
\text { - } \quad \text { Yes } \\
\text { - } \quad \text { No }\end{array}$ & $\begin{array}{c}200 \\
32\end{array}$ & $\begin{array}{c}86.2 \\
4.4\end{array}$ & $\begin{array}{c}32 \\
696\end{array}$ & $\begin{array}{l}13.8 \\
95.6\end{array}$ & 642.50 & $<0.001^{*}$ \\
\hline
\end{tabular}

* Significant at a level of $<0.05$ 
Table (6): Distribution of examined students with vision defect according to their quality of life

\begin{tabular}{|c|c|c|c|c|c|c|}
\hline & \multicolumn{4}{|c|}{ Vision defect } & \multirow{3}{*}{$\begin{array}{c}\chi^{2} \\
\text { Test }\end{array}$} & \multirow[t]{3}{*}{ P value } \\
\hline & \multicolumn{2}{|c|}{ Yes } & \multicolumn{2}{|c|}{ No } & & \\
\hline & $\begin{array}{c}\text { No } \\
(\mathbf{2 3 2})\end{array}$ & $\%$ & $\begin{array}{c}\text { No } \\
(\mathbf{7 2 8})\end{array}$ & $\%$ & & \\
\hline $\begin{array}{l}\text { Feeling happiness } \\
\text { - Yes } \\
\text { - No }\end{array}$ & $\begin{array}{c}188 \\
44\end{array}$ & $\begin{array}{l}81.0 \\
19.0\end{array}$ & $\begin{array}{c}16 \\
712\end{array}$ & $\begin{array}{c}2.2 \\
97.8\end{array}$ & 653.40 & $<0.001^{*}$ \\
\hline $\begin{array}{l}\text { Doing everything easily } \\
\text { - Yes } \\
\text { - No } \\
\end{array}$ & $\begin{array}{c}78 \\
154 \\
\end{array}$ & $\begin{array}{l}33.6 \\
66.4 \\
\end{array}$ & $\begin{array}{c}0 \\
728\end{array}$ & $\begin{array}{c}0.0 \\
100.0\end{array}$ & 266.40 & $<0.001^{*}$ \\
\hline $\begin{array}{l}\text { Feeling angry when doing things } \\
\text { - Yes } \\
\text { - No }\end{array}$ & $\begin{array}{c}138 \\
94\end{array}$ & $\begin{array}{l}59.5 \\
40.5\end{array}$ & $\begin{array}{c}6 \\
722\end{array}$ & $\begin{array}{c}0.8 \\
99.2\end{array}$ & 474.80 & $<0.001^{*}$ \\
\hline $\begin{array}{l}\text { Stud. Work } \\
\text { - Yes } \\
\text { - No }\end{array}$ & $\begin{array}{c}152 \\
80\end{array}$ & $\begin{array}{l}65.5 \\
34.5 \\
\end{array}$ & $\begin{array}{c}0 \\
728\end{array}$ & $\begin{array}{c}0.0 \\
100.0\end{array}$ & 566.70 & $<0.001^{*}$ \\
\hline $\begin{array}{l}\text { Understanding } \\
\text { - Yes } \\
\text { - No }\end{array}$ & $\begin{array}{c}156 \\
76\end{array}$ & $\begin{array}{l}67.2 \\
32.8 \\
\end{array}$ & $\begin{array}{c}0 \\
728\end{array}$ & $\begin{array}{c}0.0 \\
100.0\end{array}$ & 584.50 & $<0.001^{*}$ \\
\hline $\begin{array}{l}\text { Achievement } \\
\text { : Yes } \\
\text { - No }\end{array}$ & $\begin{array}{l}124 \\
108\end{array}$ & $\begin{array}{l}53.4 \\
46.6\end{array}$ & $\begin{array}{c}0 \\
728\end{array}$ & $\begin{array}{c}0.0 \\
100.0\end{array}$ & 446.80 & $<0.001^{*}$ \\
\hline $\begin{array}{l}\text { Planning with friends } \\
\text { - Yes } \\
\text { - No }\end{array}$ & $\begin{array}{l}102 \\
130\end{array}$ & $\begin{array}{l}44.0 \\
56.0\end{array}$ & $\begin{array}{c}0 \\
728\end{array}$ & $\begin{array}{c}0.0 \\
100.0\end{array}$ & 358.10 & $<0.001^{*}$ \\
\hline $\begin{array}{l}\text { Total score(No./\%) } \\
\text { : Poor } \\
\text {. Good }\end{array}$ & $\begin{array}{l}106 \\
126\end{array}$ & $\begin{array}{l}45.7 \\
54.3\end{array}$ & $\begin{array}{c}728 \\
0\end{array}$ & $\begin{array}{c}100.0 \\
0.0\end{array}$ & 455.10 & $<0.001^{*}$ \\
\hline
\end{tabular}

* Significant at a level of $<0.05$ 
الملخص العربي

جودة الحياة بين طلاب المدارس الابتدائية الذين يعانون من أخطاء انكسارية في المنوفية ـ مصر نجوي نشات حجازي- نجوي فر اج- زينب قاسمي

الخلفية:الاخطاء الانكسارية هو عجز العين في التركيز الضوء على الثبكية مما يؤدي إلى قصر النظر او طول النظر. ترتبط الاخطاء الانكسارية غير المصححة بضعف جودة الحياة وتقليل الفرص التعليمية لاى الأطفال الذين يعانون من ذلك.الأهداف: تهدف هذه الدراسة إلى تقييم أثر الأخطاء الانكسارية بين أطفال المدارس الابتدائية على جودة حياتهم. المنهجية و طرق البحث: تم تصميم در اسة مقطعية وصفية و أجريت الدر اسة على 960 طالب من طلاب المرحلة الابتدائية في مدرسة منشاة سلطان الابتدائية ،مركز منوف ، المنوفية و الذين يتراوح اعمار هم بين 6 الي 12 عام فى خلال الفترة من 1 أكثوبر 2016 حتى نهاية شهر ديسمبر عام 2016.و تم تقييم المشاركين من خلال استبيان يتضمن (البيانات الاجتماعية الديمو غر افية والتاريخ الثامل) و الفحص العام الاكلينيكي والبصري. و تم ايضا تقييم جودة الحياة للمشاركين باستخدام استبيان يتكون من 7 عنصرًا.و تم اختبار موثوقية باستخدام ألفا كرونباخ ـ النتائج: ولقد أظهرت الدر اسة ان أربعة وعشرون بالمائة (1و24\%) كان لديهم خطأ انكساري في احدى أو كلتا العينين. وكان هناك فرق ذو دلالة إحصائية كبيرة بين الطلاب الذين يعانون والذين لا يعانون من اخطاء انكسارية فيما يتعلق الخصائص الديمجر افية وجميع دلالات جودة الحياة بشكل عام ومن بينهم 5و45٪ من الطلاب الذين لديهم اخطاء انكسارية كانو ا يعانون من ضعف فى جودة الحياة. الخلاصة: إن فحص الأخطاء الانكسارية في أطفال المدارس الابتدائية إلزامي لبدء التدابير التصحيحية في المرحلة المبكرة ، وتقليل العجز البصري وتحسين نوعية الحياة. 